\section{VÁLTOZÁSOK A HALANDÓSÁGJAVULÁS MINTÁZATÁBAN MAGYARORSZÁGON}

Vékás Péter, Ph.D. ${ }^{1}$ (egyetemi adjunktus, Budapesti Corvinus Egyetem, Operációkutatásés Aktuáriustudományok Tanszék)

\section{ÖSSZEFOGLALÓ}

A halandóság csökkenéséből fakadó élettartam-kockázat hosszú távon jelentős pénzügyi következményekkel járhat a nyugdíj-, élet- és egészségbiztosításban egyaránt. Nem véletlen tehát, hogy a halandóság-elörejelző módszerek - sokrétü demográfiai alkalmazásaik mellett - fontos szerepet töltenek be az aktuáriusi módszertanban.

A népszerű Lee-Carter modell nem képes figyelembe venni azt a rotáció néven ismert jelenséget, miszerint a halandóság javulása jellemzően lassul az alacsonyabb életkorokban, és ezzel párhuzamosan gyorsul az idősebb korcsoportokban.

Jelen tanulmány a hazai életkoronkénti néphalandósági ráták hosszú idősorainak statisztikai vizsgálata alapján arra a következtetésre jut, hogy a halandóságjavulás rotációja a férfiak esetében gyengén, a nők esetében pedig erősen kimutatható az adatokból, illetve a Lee-Carter modell rotációt figyelembe vevő változata alapján illusztrálja, hogy a hosszú távú előrejelzésekben súlyos torzulást okozhat a rotáció figyelmen kívül hagyása.

\section{SUMMARY}

Longevity risk resulting from decreasing mortality rates may have serious financial consequences in pension, life and health insurance. Thus not coincidentally, mortality forecasting techniques play an important role in actuarial methodology, besides their various applications in demography.

The popular Lee-Carter model is unable to capture the deceleration of mortality improvements at lower ages, accompanied by the simultaneous acceleration of mortality decline at more advanced ages, an empirical phenomenon also known as the rotation of the age pattern of mortality decline.

This paper concludes that rotation is weakly present in long time series of mortality rates of Hungarian men and strongly present in similar data of Hungarian women. Based on the rotated variant of the Lee-Carter model, it is also demonstrated that ignoring rotation may lead to severe distortions in long-term forecasts.

Kulcsszavak: halandóság, élettartam-kockázat, előrejelzés, Lee-Carter modell, rotáció Key words: mortality, longevity risk, forecasting, Lee-Carter model, rotation

JEL: G22, C53
DOI: $10.18530 /$ BK.2018.3.34

http://dx.doi.org/1018530/BK.2018.3.34

\section{Bevezetés}

Az emberi halandóság az előző évszázad kezdete óta jelentősen mérséklődött (Tuljapurkar et al., 2000), ami a várható élettartamok példa nélküli emelkedésével járt. Bár a halandóság csökkenése hosszú távon az emberi populációk többségében megfigyelhetö, annak üteme erőteljesen függ a vizsgált korcsoporttól, nemtől és országtól (Lee, 2000), sőt, a naptári év függvényében - azonos korcsoport, nem és ország esetén is - jelentős változékonyságot mutat (Kannisto et al., 1994, Horiuchi-Wilmoth, 1995, Lee-Miller, 2001, Carter-Prskawetz, 2001, Rau et al., 2008).

\subsection{Rotáció a halandóságjavulás életkor szerinti mintázatában}

Számos kutató felfigyelt arra, hogy míg hosszú távon a halandóságjavulási ráták a fiatal életkorokban csökkennek, addig ezzel párhuzamosan az idősebb korcsoportokban a halandóság gyorsuló ütemben csökken (Christensen et al., 2009). Li et al. (2013) ezt a jelenséget a halandóságjavulás életkor szerinti mintázata „rotációjának” nevezik, amely az 1. ábrán egy óramutató járásával ellentétes irányú forgatással mutatható be szemléletesen.

1. ábra: Rotáció a halandóságjavulás életkor szerinti mintázatában (stilizált illusztráció)

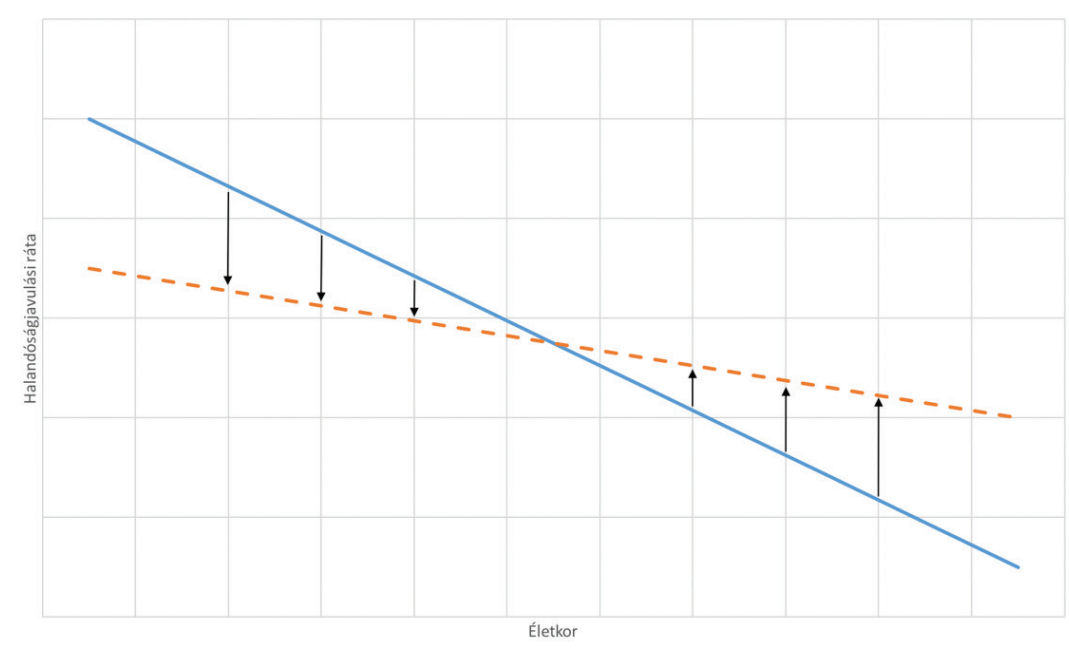

Forrás: saját szerkesztés 
A rotáció intuitív magyarázata, hogy míg régebben a várható élettartam növekedését elsősorban a gyors ütemben csökkenő csecsemő- és gyermekhalandósági ráták okozták (például a védőoltások elterjedésének vagy a javuló gyermekélelmezésnek köszönhetően), addig jelenleg e téren már kevesebb lehetőség van látványos fejlődésre, viszont ezzel párhuzamosan egyre szélesebb körben elérhetők az elörehaladott korú egyének élettartamát meghosszabbítani képes, költséges orvosi kezelések. Itt fontos megjegyezni, hogy jelen cikknek nem célja a rotáció okainak részletesebb vizsgálata.

A téma gyakorlati jelentőségét az adja, hogy a rotáció figyelmen kívül hagyásával készített hosszú távú előrejelzések szisztematikusan alulbecsülik az időskorú népességet, és így az élettartam-kockázat (az angol aktuáriusi szaknyelvben longevity risk néven ismert kifejezés Májer-Kovács, 2011 által meghonosított magyar fordítása) negatív hatásai erőteljesebben jelentkeznek a nyugdíj-, élet- és egészségbiztosítással foglalkozó intézmények pénzügyi kimutatásaiban.

Jelen tanulmány azt vizsgálja, hogy vajon kimutatható-e a rotáció a magyarországi férfiak és nők halandósági idősoraiban, illetve hogy annak figyelmen kívül hagyása vajon jelentősen torzíthatja-e az aktuáriusok által is alkalmazott hosszú távú halandóság-elörejelzéseket.

\subsection{A Lee-Carter modell}

A halandóság-előrejelző módszerek (Booth-Tickle, 2008 és Pitacco et al., 2009) fontos szerepet játszanak az élet- és nyugdíjbiztosításban és a demográfiában. A népszerű LeeCarter (1992) modell megalkotása valószínűleg a halandóság-elörejelzés történetének legnagyobb áttörése volt. A szerzők az $x$ korcsoport $t$ naptári évi központi halandósági rátájának logaritmusát az

$$
\ln m_{x t}=a_{x}+b_{x} k_{t}+\varepsilon_{x t}
$$

egyenlettel írják le, ahol ax az adott korhoz tartozó központi halandósági ráták logaritmusainak átlaga, a $k_{t}$ idősor a halandóság általános alakulását képezi le, valamint a $b_{x}$ paraméterek jellemzik a halandóságcsökkenés életkoronkénti ütemét. Mivel a $b_{x}$ paraméterek nem függenek a naptári évtől, és a $k_{t}$ idősorról többnyire feltételezik, hogy lineárisan alakul (Tuljapurkar et al., 2000), ezért a halandóság életkoronkénti csökkenési üteme a Lee-Carter modellben időben állandó, és csak a kérdéses egyén életkorától függ. Az utóbbi implicit feltételezés jogosságát tudományos és szakmai körökben egyaránt sokan megkérdőjelezték az elmúlt évtizedekben.

\subsection{Az állandó ütemü életkoronkénti halandóságjavulás empirikus cáfolata}

Kannisto et al. (1994) a 80-99 éves korcsoportban gyorsuló halandóságjavulást állapítanak meg 27 ország 1950 és 1989 közötti adatsorai alapján. Horiuchi-Wilmoth (1995) svéd adatok alapján következtetnek arra, hogy a halandóságjavulás a fiatalabb korcsoportokból áthelyeződött az idősebb korosztályokba. Lee-Miller (2001) a XX. század első és második felében tapasztalt életkoronkénti átlagos halandóságjavulási rátákat vetik össze egymással, és ezzel az egyszerü módszerrel számos országban kimutatják a javulás eltolódását az idősebb korcsoportok felé. Emiatt a szerzők az 1950 utáni évek adatait javasolják a LeeCarter modell becslésére. Carter-Prskawetz (2001) különböző időablakokon becsülnek Lee-Carter modelleket Ausztria halandósági adatain, így illusztrálva az életkoronkénti halandóságjavulási ráták alakulását. Rau et al. (2008) és Christensen et al. (2009) megállapítják, hogy a 80 évesnél idősebb népesség halandósági rátái többnyire - és néhány esetben gyorsuló ütemben - csökkentek az általuk vizsgált 30 országban.

\subsection{Modellezési megközelitések}

A szakirodalomban különböző megoldások ismertek a klasszikus Lee-Carter modellkeret azon megszorító megkötésének feloldására, miszerint az életkoronkénti halandóságjavulási ráták időben állandók. Különösen ígéretes Li et al. (2013) rotált Lee-Carter modell néven is ismert módszere, amelynek egyik szerzője az eredeti modellt jegyző Ronald D. Lee professzor. Ebben a modellváltozatban az (1) egyenletben szereplő $b_{x}$ paraméterek az idő függvényei, melyek a születéskor várható élettartam egy bizonyos szintjének elérését követően elkezdenek fokozatosan megváltozni (a rotáció jellemző mintázata alapján fiatalabb korcsoportokban csökkenni, illetve idősebb korosztályok esetén növekedni), és az idő múlásával, hosszú távon egy szakmai szempontok alapján feltételezett végső görbéhez konvergálni. A rotált Lee-Carter modell részletes bemutatására a felhasznált adatokat és módszereket ismertető 2. szakaszban kerül majd sor.

Fontos megjegyezni, hogy a szerzők modelljüket alacsony halandóságú országokra és nagyon hosszú elörejelzési időtávokra javasolják. Az eredeti Lee-Carter modell becsült paramétereinek ismerete önmagában elegendő a rotált modell illesztéséhez. Ezenkívül az eredeti eljárás helyett annak Li-Lee (2005) által ismertetett, koherens férfi és női halandósági rátákat generáló továbbfejlesztése is szolgálhat az eljárás kiindulópontjául. Míg ebben a modellváltozatban a $b_{x}$ paraméterek nemtől függenek, addig a két nemhez tartozó $a_{x}$ és $k_{t}$ paraméterek azonosak.

A rotált Lee-Carter modell gyakorlati jelentőségét mutatja, hogy Ševčíková et al. (2016) és Dion et al. (2015) a közelmúltban a United Nations Population Division és a Statistics Canada hivatalos népesség-előrejelző modelljeibe építették be azt. 
További lehetőség a rotáció megragadására, ha Haberman-Renshaw (2012) és Mitchell et al. (2013) javaslata alapján a halandósági ráták helyett a halandóságjavulási ráták képezik a szokásos módszerekkel (például az eredeti Lee-Carter modell alapián) készített elörejelzések tárgyát. Bohk-Ewald-Rau (2017) ezt a megoldást olyan bayes-i modellkeretbeágyazza be, amely képes különböző országok halandósági trendjeit és az azok közötti interakciókat együttesen is modellezni, és nagy-britanniai, valamint dániai adatokon szemléltetik, hogy az állandó életkoronkénti halandóságjavulás feltételezése a születéskor várható élettartam alábecsüléséhez vezet. Bohk-Ewald-Rau (2016) ezt a modellkeretet az Egyesült Államok adatain alkalmazzák. Ezek a megközelítések adatvezéreltek, szemben a Li et al. (2013) által javasolt rotált Lee-Carter modellel, amely az életkoronkénti halandóságjavulási ráták alakulását bizonyos értelemben önkényesen választott folyamatként modellezi, mivel a szerzők úgy vélik, hogy túl csekély a rotáció empirikus bizonyítéka ahhoz, hogy önmagában vezérelje az előrejelzéseket.

Egy másik alternatív megközelítést mutatnak be Booth et al. (2002) és HyndmanUllah (2007), akik abból indulnak ki, hogy míg az (1) egyenletben egy-egy életkortól és naptári évtől függő paraméter interakciója szerepel, addig az interakciók számát növelve rugalmasabbá tehető a Lee-Carter modellkeret. Az így kapott modelleket többtényezős halandóság-előrejelző eljárásoknak is nevezik, szemben az egytényezős Lee-Carter modellel.

Bongaarts (2005) eltolásos logisztikus modellel írja le a halandóságjavulás életkor szerinti mintázatának megváltozását. Li-Lee (2005), Cairns et al. (2011), Russolillo et al. (2011) és Hyndman et al. (2013) különböző népességek halandóságát koherens modellkeretben jelzik előre. Az ilyen többpopulációs modellekben az életkoronkénti halandóságjavulási ráták nem feltétlenül állandók a különböző populációk egymásra hatása miatt. A közelmúltban született egyéb alternatív megközelítések között érdemes még megemlíteni De Beer-Janssen (2016) cikkét, akik az elhalálozáskori életkorok eloszlását naptári évenként modellezik, valamint Li-Li (2017) tanulmányát, akik egy szekvenciálisan végrehajtható statisztikai tesztet javasolnak annak meghatározására, hogy melyik időpontban kezdődik a leghosszabb olyan, a jelenig tartó becslési időszak, amelyben a $k_{t}$ idősor linearitása és a $b_{x}$ paraméterek állandósága együttesen fennállnak. A szerzők szerint az általuk vizsgált 34 ország többségében ez az időszak valahol 1960 és 1990 között kezdődik.

\subsection{Hazai kutatások}

Májer-Kovács (2011) a 65-100 évesek 1970-2006. évi halandósági rátáira a Lee-Carter modellt illesztik, és a klasszikus statikus halandósági tábla, valamint a halandóság előrevetítése alapján egyaránt kiszámítják a nyugdíjkorhatáron várható hátralévő élettartamot és a nyugdíjkorhatáron induló életjáradék egyszeri nettó díját. Eredményeik alapján a nyugdíjazáskor várható élettartamot 6,33 százalékkal, az életjáradék egyszeri nettó díját pedig 4,51 százalékkal becsüli alá az élettartam-kockázatot figyelmen kívül hagyó, keresztmetszeti számítás. A szerzők két eltérő megközelítésben közölnek konfidencia-intervallumokat a nyugdíjazáskor várható élettartamra és az életjáradék egyszeri nettó díjára. Megmutatják továbbá, hogy élettartam-kockázat jelenlétében még végtelen nagy kockázatközösség esetén, határértékben sem válik kockázatmentessé a nyugdíjcélú életjáradék nyújtása a járadékszolgáltató számára.

Mivel a járadékban részesülők halandósága jelentősen eltérhet a néphalandóságtól, és a hazai életjáradék-piac rövid története és alacsony volumene miatti szűkös tapasztalatok általában nem teszik lehetővé a járadékszolgáltatók számára a megbízható, állományspecifikus halandósági táblák készítését, ezért Arató et al. (2009) más országok olyan, múltbeli halandósági tábláinak használatát javasolják, amelyek kellően jól írják le a vizsgált állomány jelenlegi halandóságát. A referenciatábla kiválasztására három lehetséges távolságmértéket javasolnak, és ismertetnek egy eljárást a táblák egyezésére vonatkozó teszt kritikus értékeinek Monte-Carlo szimulációjára. A szerzők megállapítják, hogy a 60-90 év közötti életkorokban az Egyesült Államok 1950. évi férfi és 1970. évi női halandósági táblái megfelelően illeszkednek a 2000. évi hazai néphalandósági adatokhoz. Bemutatnak továbbá egy paraméteres halandósági törvényre épülő előrejelző eljárást, valamint annak egy lehetséges alkalmazását is.

\section{A járadékban részesülők halandósága jelentősen eltérhet a néphalandóságtól.}

Baran és szerzőtársai (2007) a Lee-Carter modell többtényezős változatát alkalmazzák hazai adatokon, és az illesztett háromtényezős modell alapján megállapítják, hogy az 1949-2003. évek adatai alapján nyert előrejelzések nem megfelelők a mortalitási indexek trendjeiben bekövetkezett strukturális törések miatt. Emiatt az 1989-2003 közötti éveket javasolják bázisidőszaknak. A szerzők szerint a modell segítségével nyert előrejelzéseket óvatosan kell kezelni a hazai halandóság múltbeli változékonysága miatt.

Arató-Dryden-Taylor (2006) hierarchikus bayes-i térstatisztikai modellt illesztenek 150 magyarországi kistérség életkorfüggő halálozási adataira. A kistérségenként különböző életkorfüggő halandósági ráták megbízhatósági intervallumait a szerzők Markov-lánc Monte-Carlo szimuláció segítségével állítják elő, és relatív kockázati szinteket is becsülnek a nem és településméret változók kategóriáira.

Ispány et al. (2010) a Lee-Carter modellben is alkalmazott szingulárisérték-felbontás általánosításait mutatják be, és a javasolt módszereket hazai néphalandósági adatok modellezésére és vizualizációjára alkalmazzák. 
A hazai halandóságot iskolázottság szerinti bontásban vizsgálja Hablicsek-Kovács (2007). A nyugdíjban és nyugdíjszerű ellátásban részesülők halandóságával foglalkoznak Hablicsekné-Hollósné (2007) és Molnár-Hollósné (2015) tanulmányai. A halálozás oka szerint bontott halandósági trendekröl szól Kovács (2012) írása.

Bajkó et al. (2015) a Lee-Carter modell alapváltozatát alkalmazzák az életkorfüggő halandósági és termékenységi ráták előrejelzésére. Az így kapott előrejelzéseket egy olyan kohorszalapú nyugdíjmodellbe építik be, amelynek célja a magyar nyugdíjrendszer fenntarthatóságának vizsgálata. A szerzők megállapítják, hogy változtatások nélkül a rendszer várhatóan 2026-tól deficitet fog mutatni, és részletesen elemzik egyes paraméteres változtatások és makrogazdasági forgatókönyvek hatásait.

A halandóságjavulás rotációja mértékének számszerüsítésére tesz kísérletet Vékás (2018) az Európai Unió 28 tagországának adatain. Az eredmények alapján arra következtet, hogy bár a rotáció a tagállamok többségében kimutatható, annak jelenléte korántsem tekinthető univerzálisnak. A nők halandósági adataiban azonban sokkal erőteljesebben jelentkezik, mint a férfiak esetén. A szerző kimutatja továbbá, hogy a rotáció mértéke - némileg meglepő módon - nem korrelál a születéskor várható élettartammal.

\section{Adatok és módszerek}

Az elemzéshez felhasznált adatok: a magyarországi férfiak és nők korcsoportos halandósági rátái és népességszámai 22 korcsoportra $(0,1-4,5-9,10-14, \ldots, 95-99$ és $100+$ évesek) és 13 ötéves naptári periódusra (1950-1955, 1955-1960, ..., 2010-2015, a kezdő és záró évek július 1. napjai közötti időszakok), valamint a nemenkénti születéskor várható élettartamok idősorai. Valamennyi adat a UN World Population Prospects 2017 (United Nations, 2018) adatbázisból származik. Az életkorok és naptári évek csoportosításának kedvező hatása, hogy kisimítja a halandósági adatsorokat (a mozgóátlagoláshoz hasonlóan), így azok kevesebb nem szisztematikus ingadozást tartalmaznak. Az itt bemutatandó számítások az $R$ programcsomag (R Development Core Team, 2008) segítségével készültek.

Az $x$ korcsoport $t$ naptári időszakbeli halandóságjavulási rátájának képlete:

$$
r_{x t}=-\ln \left(\frac{m_{x, t+1}}{m_{x t}}\right) \text {. }
$$

Ezekből az adott korcsoport halandóságjavulási rátáinak idősorára illesztett lineáris regressziós egyenes meredekségeként számítható ki a halandóságjavulás átlagos gyorsulási rátája az adott korcsoportban:

$$
\beta_{x}=\frac{\sum_{t=1}^{12}\left(r_{x t}-\bar{r}_{x}\right)(t-\bar{t})}{\sum_{t=1}^{12}(t-\bar{t})^{2}}
$$

A rotáció jelenlétének kimutatásához azt szükséges megvizsgálni a halandósági idősorokban, hogy vajon pozitív irányú-e a kapcsolat az életkor és a gyorsulás mértéke között. Mivel a korcsoport ordinális változó, és a pozitív irányú kapcsolat nem szükségszerűen lineáris, ezért a népszerű Spearman-féle $\rho$ rangkorrelációs együttható alkalmas és kézenfekvő mérőszáma lehet a rotáció erösségének. Ez a megközelítés a korcsoportok létszámai szerinti súlyozás révén további finomítást igényel, hiszen a népesebb korcsoportokat nyilvánvalóan reálisabb nagyobb súllyal figyelembe venni a rotáció erősségének mérésekor. A rotáció mérésére alkalmas méröszám tehát a korcsoportok és a gyorsulási ráták közötti, létszámokkal súlyozott Spearman-féle $\rho$ rangkorrelációs együttható (Vékás, 2018, illetve Pinto da Costa, 2015), melynek képlete:

$$
\rho=\frac{\sum_{x=1}^{22} P_{x}\left(\operatorname{rank}\left(\beta_{x}\right)-\mu\right)(x-v)}{\sqrt{\sum_{x=1}^{22} P_{x}\left(\operatorname{rank}\left(\beta_{x}\right)-\mu\right)^{2}} \sqrt{\sum_{x=1}^{22} P_{x}(x-v)^{2}}},
$$

ahol

$$
\mu=\frac{\sum_{x=1}^{22} P_{x} \operatorname{rank}\left(\beta_{x}\right)}{\sum_{x=1}^{22} P_{x}} \quad \text { és } \quad v=\frac{\sum_{x=1}^{22} P_{x} x}{\sum_{x=1}^{22} P_{x}}
$$

g gyorsulási rátákból növekvő sorrendben képzett (holtverseny esetén átlagos) rangszámok, illetve a megfelelő korcsoport-indexek létszámokkal súlyozott átlagai.

Rotáció jelenlétében érdemes lehet a rotált Lee-Carter modell néven ismert eljárást alkalmazni, amely a rotációt az eredeti Lee-Carter modellbe építi be, és a központi halandósági ráták logaritmusait az (1) egyenlet helyett a

$$
\ln m_{x t}=a_{x}+B(x, t) k_{t}+\varepsilon_{x t}
$$

összefüggéssel írja le. A (6) egyenletben szereplő $B(x, t)$ paraméterek ragadják meg a rotációs jelenséget azáltal, hogy a naptári idő múlásával az (1) egyenletbeli $b_{x}$ értékekről kiindulva folytonosan a szakmai szempontok alapján feltételezett végső értékeikhez konvergálnak, amint az eredeti Lee-Carter modellben a születéskor várható élettartam egy küszöbértékről egy felső plafonhoz közeledik (a szerzők az utóbbi két értékre 80 és 102 évet javasolnak).

A $B(x, t)$ paraméterek alakulását leíró egyenlet:

$$
B(x, t)=\left\{\begin{array}{cc}
b_{x}, & e_{t}^{0}<80 \\
(1-w(t)) b_{x}+w(t) b_{x}^{u}, & 00 \leq e_{t}^{0}<102 \\
b_{x}^{u}, & e_{t}^{0} \geq 102
\end{array}\right.
$$


ahol $b_{x}$ az (1) egyenlet szerinti, eredeti Lee-Carter modell megfelelő paramétere, $b_{x}{ }^{u}$ a feltételezett végső érték, a $w(t)$ súly pedig az eredeti Lee-Carter modell alapján elöre jelzett $e_{t}^{0}$ születéskor várható élettartam (8) szerinti növekvő, sima függvénye:

$$
w(t)=\left\{\frac{1}{2}\left[1+\sin \left[\frac{\pi}{2}\left(2 \frac{e_{t}^{0}-80}{102-80}-1\right)\right]\right]\right\}^{p} .
$$

A (8) egyenletben a $p$ kitevő a konvergencia sebességét határozza meg (a szerzők alapesetben a $p=0,5$ értéket javasolják).

A feltételezett végső értékeket megadó egyenlet:

$$
b_{x}^{u}=\left\{\begin{array}{cc}
\frac{1}{50} \sum_{i=15}^{64} b_{i}, & x \leq 64, \\
\alpha b_{x}, & x>64,
\end{array}\right.
$$

ahol az $\alpha$ paramétert úgy kell megválasztani, hogy az eredeti modellből örökölt

$$
\sum_{x=0}^{\omega} b_{x}^{u}=1
$$

megkötés teljesüljön. A (9) egyenlet intuitív tartalma, hogy a nyugdíjkorhatárt megelőző életkorokban az idő múlásával egyre kevesebb bizonyossággal feltételezhetünk bármit a halandóságjavulás életkor szerinti mintázatáról, így annak alakja egyre inkább vízszintes egyenessé simul, valamint ezzel párhuzamosan a fiatalkori értékek csökkenése következtében az időskori értékeknek nőniük kell a (10) megkötés miatt, így a modellben megvalósul a rotáció.

Érdemes megjegyezni még, hogy az itt ismertetett (6)-(10) összefüggések a Li-Lee (2005) által javasolt, hosszú távon koherens férfi és női halandósági rátákat generáló modellváltozat használata esetén is változatlanul érvényesek. Azonban mivel ez a változat nemenként azonos $b_{x}$ paramétereket tételez fel, ezért ebben az esetben $\mathrm{B}(x, t)$ és $b_{x}{ }^{\text {u }}$ egyaránt uniszex paraméterek, valamint a (8) egyenlet jobb oldalán értelemszerűen uniszex várható hátralévő élettartamok szerepelnek.

\section{Eredmények}

Az 1. táblázatban láthatók a (4) egyenlet alapján a rotáció erősségét mérő Spearman-féle $\rho$ rangkorrelációs együttható értékei, illetve a

$$
H_{0}: \rho \leq 0, \quad H_{1}: \rho>0
$$

hipotézispárhoz tartozó $z$-teszt (Pinto da Costa, 2015) p-értékei férfiak és nők esetén.
Az 1. táblázat eredményei alapján mind a férfiak, mind a nők esetében kimutatható a rotáció, azonban míg annak erőssége férfiak esetén 5 százalékos szignifikanciaszinten csak épphogy szignifikáns, addig a nők esetében jóval erősebb a bizonyíték a rotáció jelenlétére. Ez összhangban áll azzal, hogy Li et al. (2013) szerint az alacsonyabb halandóságú populációkban jellemzőbb a rotáció.

1. táblázat: A rotáció erőssége és szignifikanciája férfiak és nők esetén

\begin{tabular}{|c|c|c|}
\hline & Férfiak & Nők \\
\hline Rotáció erössége $(p)$ & 0,385 & 0,546 \\
\hline Szignifikancia $(p)$ & 0,048 & 0,006 \\
\hline
\end{tabular}

Forrás: saját szerkesztés

A rotált Lee-Carter modell alkalmazásával akár 2100-ig is megkaphatók a $B(x, t)$ paraméterek előrejelzései. A Lee-Carter modell Li-Lee (2005) által javasolt koherens változatából (a továbbiakban: rotációmentes modellváltozat) kiinduló, rotált Lee-Carter modell szerinti uniszex $B(x, t)$ paraméterek előrejelzései a 2. ábrán láthatók.

\section{2. ábra: A B(x,t) paraméterek alakulása 2100-ig és a feltételezett végső értékek}

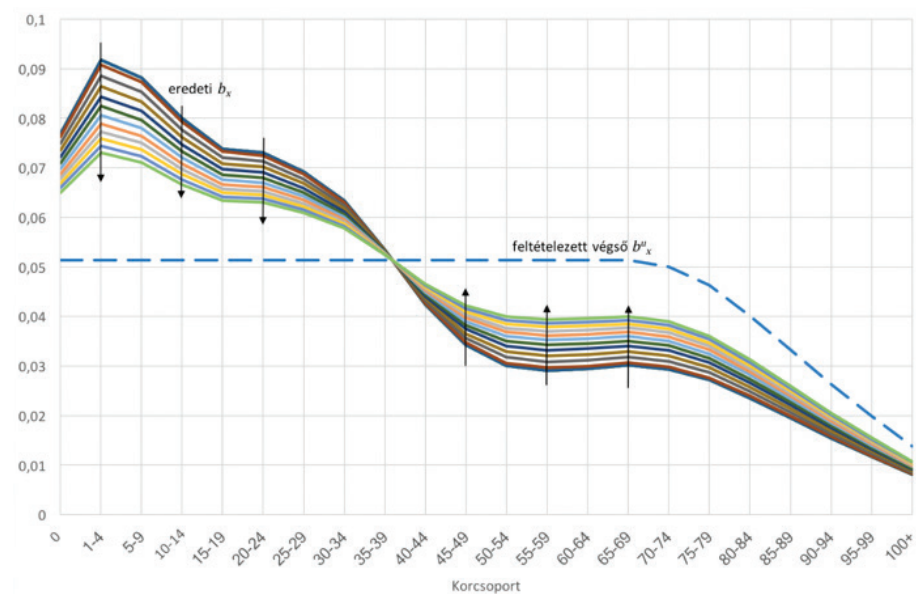

Forrás: saját szerkesztés

Az ábra alapján a rotációmentes változat $b_{x}$ paraméterei erősen csökkenő görbén helyezkednek el: a halandóságjavulás jellemzőbb fiatal, mint idősebb korokban. A rotált modellváltozat jóslata alapián azonban ez a görbe 2015 és 2100 között fokozatosan el fog fordulni az óramutató járásával ellentétes irányban: tehát míg fiatalabb korokban lassul, addig az idősebb életkorokban 
fokozatosan gyorsul majd a halandóságjavulás. Ennél is hosszabb időtávon a modell alapján a $B(x, t)$ paraméterek görbéje a 2. ábrán szaggatottal jelölt, feltételezett végső $b_{x}{ }^{\mathrm{u}}$ paraméterek görbéjéhez konvergál majd.

A 3. ábra szemlélteti, hogy a rotáció figyelmen kívül hagyása hosszú távon milyen jelentős előrejelzési hibákhoz vezethet. Az ábrán három kiválasztott korcsoport (0, 50-54 és 80-84 évesek) 2100-ig előre jelzett logaritmikus mortalitási rátái láthatók a rotációmentes és a rotált változatok alapián. Jól látható, hogy az előrejelzési időszak hosszának növelésével a két eljárás által előre jelzett ráták egyre inkább eltávolodnak egymástól.

\section{3. ábra: A B(x,t) paraméterek alakulása 2100-ig és a feltételezett végső értékek}

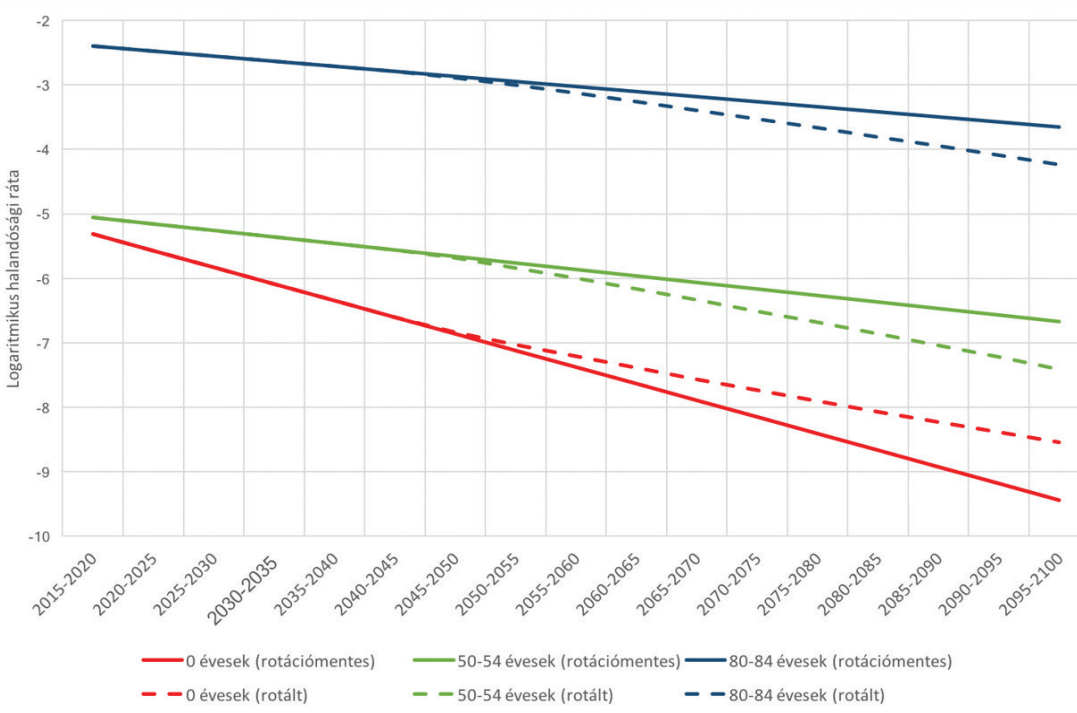

Forrás: saját szerkesztés

A 0 évesek esetén a rotált modellváltozat használata eredményez magasabb becsült rátákat, hiszen ez - a rotációmentes eljárással ellentétben - figyelembe veszi a csecsemőhalandóság csökkenésének lassulását. Másfelől az 50-54 és 80-84 évesek esetén a rotált modell a rotációmentes eljárásnál alacsonyabb rátákat jelez előre, mert ez a változat képes figyelembe venni azt, hogy a magasabb korosztályokban a halandóság csökkenése folyamatosan gyorsul.

Az eltérés a két változat előrejelzései között hosszú távon rendkívül jelentős: például a 0 évesek logaritmikus halandósági rátáját a 2095-2100 közötti időszakban a rotációmentes eljárás a rotált változathoz képest 0,893 egységgel alábecsüli. Másképpen fogalmazva, a rotált modellváltozat szerint ebben az időszakban $e^{0,893} \approx 2,442$-szer magasabb lesz a csecse- mőhalandósági ráta a rotációt figyelmen kívül hagyó becsléshez képest! Bár jogos felvetés megkérdőjelezni a 2100-ig történő előrejelzés hasznosságát, de az eltérés már néhány évtizedes időtávon is jelentős.

A 4. ábra valamennyi korcsoport esetén szemlélteti a rotált és a rotációmentes modellváltozatok segítségével a 2095-2100 periódusra előre jelzett halandósági ráták hányadosait. Ha a két változat azonos eredményt szolgáltatna, akkor a folytonos görbe a szaggatott egyenessel esne egybe.

4. ábra: A rotált és a rotációmentes modellváltozatok alapján a 2095-2100 időszakra elöre jelzett halandósági ráták hányadosai korcsoportonként

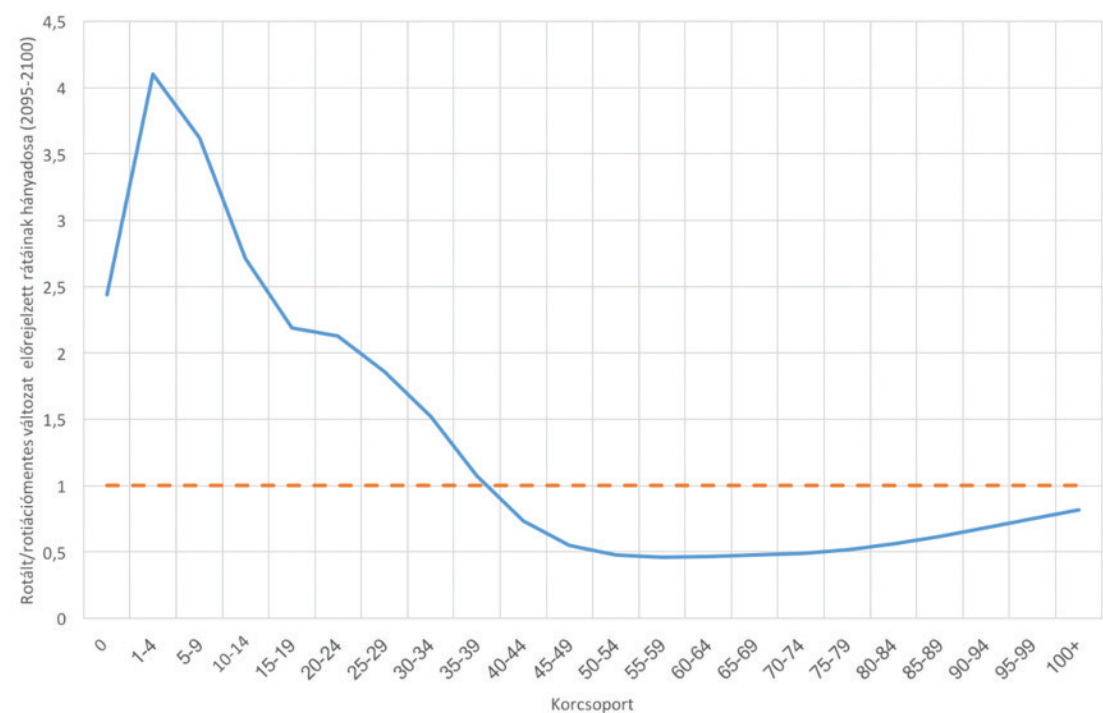

Forrás: saját szerkesztés

Az ábrán jól látható, hogy míg például az 1-4 évesek csoportjában a kapott hányados a 4-et is meghaladja, addig a 60-64 évesek körében 0,5-nél is alacsonyabb értéket vesz fel. Nem túlzás kijelenteni tehát, hogy a hazai adatokra vonatkozó, hosszú távú halandóság-előrejelzésekben kiemelt jelentősége van a rotáció figyelembevételének.

\section{Összegzés}

Jelen tanulmány a hazai szakirodalomban elsőként mutatja be a rotáció néven ismert jelenséget a halandóságjavulás életkor szerinti mintázatában, valamint áttekintést nyújt a témával kapcsolatos nemzetközi és a halandóság-előrejelzésekkel kapcsolatos hazai kutatásokról. 
Részletesen ismerteti azt a módszertant és azon eredményeket, amelyek segítségével 22 korcsoport 1950-2015 közötti halandósági rátái alapján alátámasztást nyert, hogy a más országokban már korábban kimutatott rotáció jelenléte a magyarországi férfiak esetén gyengén, a hazai női népességben pedig erősen kimutatható, és 5 százalékos szignifikanciaszinten mindkét nem esetében statisztikailag szignifikáns.

Végezetül a tanulmány a Lee-Carter modell rotációt figyelembe vevő változata alapján illusztrálja, hogy a magyarországi adatok alapján készített hosszú távú halandóság-elörejelzésekben rendkívül súlyos torzítást okozhat a rotáció figyelmen kívül hagyása, ami nyilvánvalóan nem lehet közömbös a kapcsolódó aktuáriusi alkalmazások szempontjából sem.

\section{Köszönetnyilvánítás}

Jelen tanulmányt az Európai Unió, Magyarország és az Európai Szociális Alap társfinanszírozása által biztosított forrásból az EFOP-3.6.2-16-2017-00017 azonosítójú „Fenntartható, intelligens és befogadó regionális és városi modellek" címü projekt finanszírozta.

\section{IRODALOMJEGYZÉK}

Arató, M. - Dryden, I.L. - Taylor, C.C. (2006): Hierarchical Bayesian modelling of spatial age-dependent mortality Computational Statistics \& Data Analysis, 51(2), pp. 1347-1363. http:///x.doi.org/10.1016/j.csda.2006.02.007.

Thes Modelling, 49(3-4), pp. 805-813. http://dx.doi.org/10.1016/j.mcm.2008.01.012.

57, pp. 21-34. http://dx.doi.org/10.1556/aoecon.57.2007.1.3.
Bohk-Ewald, C. - Rau, R. (2016): Changing Mortality Patterns and Their Predictability: The Case of the United States. In Schoen, R. editor, Dynamic Demographic Analysis. The Springer Series on Demographic Methods and Population Analysis, volume 39. Springer

of Population Sciences, 73 (1). https://doi.org /10.1186/s411118-016-0017-8

Bongaarts, J. (2005): Long-range trends in adult mortality: Models and projection methods. Demography, 42(1), pp. 23-49. https://doi. org/10.1353/dem.2005.0003.

. http://dx.doi.org/10.1017//1748499500000440.

Booth, H. - Maindonald J.-Smith, L. (2002): Applying Lee-Carter under Conditions of Variable Mortality Decline. Population Studies, 56(3), pp. 325-336. http://dx.doi.org/10.1080/00324720215935.

Cairns, A.J.G. - Blake, D. - Dowd, K. - Coughlan, G.D. - Khalaf-Allah, M. (2011): Bayesian Stochastic Mortality Modelling for Two Carter, L.R. - Prskawetz, A. (2001): Examining structural shifts in mortality using the Lee-Carter method (working paper). Max Planck Institute for Demographic Research. https://www.demogr.mpg.de/Papers/Working/wp-2001-007.pdf. Letöltés dátuma: 2018.07.21.

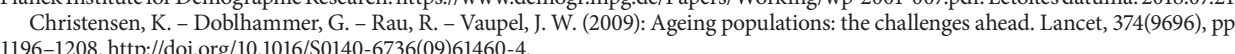
http://doi.org/10.1186/12963-016-0113-1. to 2038): Technical Report on Methodology and Assumptions. Statistics Canada. https://www150.statcan..gc.ca/n1//en/catalogue/91-620-X.

Haberman, S. - Renshaw A. (2012): Parametric mortality improvement rate modelling and projecting. Insurance: Mathematics and Economics, 50(3), pp. 309-333. https:///doi.org/10.1016/ji.insmatheco.2011.11.005.

Hablicsek, L. - Kovacs, K. (2007): Azeeletkilatások differencialódasasa iskolazottság szerint, 1986-2005. KSH Népességtudományi Kutatóin-

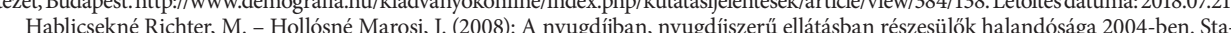
tisztikai Szemle, 86(9),pp. 875-898. http:///www.ksh.hu//statszemle_archive/2008/2008_09/2008_09_875.pdf. Letöltés dátuma:2018.07.21.
Horiuchi, S. - Wilmoth, J.R. (1995): The Aging of Mortality Decline. Annual Meeting of the Population Association of America. San rancisco, $\mathrm{CA}$

tes: a functional data approach. Computational Statistics \& Data Analysis, 51(10), pp. 4942-4956. http://dx.doi.org/10.1016/j.csda.2006.07.028. models. Demography, 50(1), pp. 261-283. http://dx.doi.org/10.1007/s13524-012-0145-5.

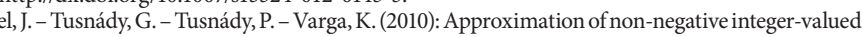
matrices with application to Hungarian mortality data. Proceedings of the 19th International Symposium on Mathematical Theory of Kannisto, V. - Lauritsen, J. - Thatcher, A.R. - Vaupel, J.W. (1994): Reductions in Mortality at Advanced Ages: Several Decades of Evidence i.org/10.2307/2137662 vanyokonline/index.php/demografiaiportre/article/view/652/220. Letöltés dátuma: 2018.07.21.

Lee, R. D. - Carter, L.R. (1992): Modeling and forecasting U.S. mortality. Journal of the American Statistical Association, 87, pp. 659-671. http://dx.doi.org/10.2307/2290201.

Thod for Forecasting Mortality, with Various Extensions and Applications. North American Actuarial .

Lee, R. - Miller, T. (2001): Evaluating the performance of the Lee-Carter method for forecasting mortality. Demography, 38(4), pp.

537-549. http://dx.doi.org/10.1353/dem.2001.0036.
Li, H. - Li, J.S. (2017): Optimizing the Lee-Carter Approach in the Presence of Structural Changes in Time and Age Patterns of Mortality 作 42(3), pp. 575-594. http:///dx.doi.org/10.1353/dem.2005.0021.

Li, N. - Lee, R. - Gerland, P. (2013): Extending the Lee-Carter method to model the rotation of age patterns of mortality-decline for long-term projections. Demography, 50(6), pp. 2037-2051. https:///doi.org/10.1007//13524-013-0232-2.
Májer. I. - Kovács. E. (2011): Elettartam-kockázat - a nyuugdírendszerre nehezedö egyik teher St htt:://www.ksh.hu/statszemle archive/2011/2011_07-08/2011_07-08_790.pdf. Letöltés dátuma: 2018.07.21.

Mitchel, D. - Brockett, P. - Mendoza-Arriaga, R. - Muthuraman, K. (2013): Modeling and forecasting mortality rates. Insurance,

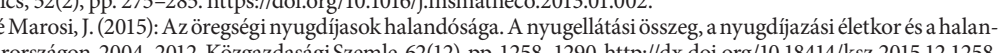
dósag összzefuggesesei Magyarorszagon, 2004-2012. Kozgazdasagi Szemle, 62(12),pp. 1258-1290. http://dx.doi.org/ 10.18414/ksz.2015.12.1258.
Pinto da Costa, J. (2015): Rankings and Preferences - New Results in Weighted Correlation and Weighted Principal Component Analysis with Applications. Springer. ISBN: 978-3- 662-48343-5.

Pitacco, E. - Denuit, M. - Haberman, S. - Olivieri, A. (2009): Modelling Longevity Dynamics for Pensions and Annuity Business.

RDevelopment Core Team (2008):
Vienna, Austria. ISBN 3-900051-07-0. Rau, R. - Soroko, E. - Jasilionis, D. - Vaupel, J.W. (2008): Cont Review, 34, pp. 747-68. http://doi.org/10.1016/50140-6736(09)61460-4. Actuarial Journal, 2011(2), pp. 96-117. https:///doi.org/10.1080/03461231003611933. Sevčíková, H. - Li, N. - Kantorová, V. - Gerland, P. - Raftery, A. E. (2016): Age-specific mortality and fertility rates for probabilistic
population projections. In Schoen, R., editor, Dynamic Demographic Analysis. The Springer Series on Demographic Methods and PopuTul https://www.researchgate.net/publication/12453012_A_Universal_Pattern_of_Mortality_Change_in_the_G7_Countries. Letöltés dátuma: 2018.07 .21 .

United Nations Population Division (2018): World Population Prospects 2017 (maintained by Ševčiková, H.). https://CRAN.R-project. Vékás P. (2018): Rotation of the ase

Journal of Operations Research. 